\title{
Antonio Lo Re: Mechanical Engineering in Agriculture
}

\section{Cristina Romano, Luigi Traetta}

Department of Humanities, University of Foggia, Foggia, Italy

Email: cristina.romano@unifg.it

How to cite this paper: Romano, C., \& Traetta, L. (2020). Antonio Lo Re: Mechanical Engineering in Agriculture. Advances in Historical Studies, 9, 344-357.

https://doi.org/10.4236/ahs.2020.95026

Received: October 30, 2020

Accepted: December 7, 2020

Published: December 10, 2020

Copyright $\odot 2020$ by author(s) and Scientific Research Publishing Inc. This work is licensed under the Creative Commons Attribution International License (CC BY 4.0).

http://creativecommons.org/licenses/by/4.0/

\begin{abstract}
In light of recent historiographic guidelines that have identified machines as the prime means by which the Industrial Revolution spread to the Italian countryside, this article explains the works and studies of Antonio Lo Re (18571920). With his ability to combine teaching, scientific research, and technological applications in a complex district like the Italian Captainate, Lo Re played a leading role not only in the agrarian science of his times, but also in related technologies, with particular attention to the machinery that the increasingly flourishing European-and, to a more modest extent, also Italian-industry in the second half of the $19^{\text {th }}$ century devoted to agricultural production. Moreover, his manuals contain valuable sketches and drawings useful in reconstructing the history of agricultural machinery of the period.
\end{abstract}

\section{Keywords}

Antonio Lo Re, History of Machines, History of Agricultural Technology

\section{Introduction}

"A highly intelligent man, well-educated in science and the humanities, an enthusiastic scholar with a vast knowledge of the climatic, geological, historical, and social conditions of the entire region of Apulia and of the Captainate in particular" - thus did Benedetto Biagi, an intellectual from Foggia, describe Antonio Lo Re-whom he had known personally-shortly after the latter's death (Biagi, 1930: p. 11). Lo Re had been inspired by a variety of research opportunities, making him one of the best-known intellectuals of his territory in the years spanning the late 19th century and the early 20th century.

Over the years, alongside some mostly 20th-century studies on his life and work, concrete local initiatives to honor Lo Re have included naming a street for him in the center of Foggia, near the public gardens in whose development the 
scholar was so involved (Lo Re, 1898b); placing a bust with a memorial plaque in the atrium of the Pietro Giannone Institute where Lo Re taught for more than three decades; and lastly dedicating a classroom to him at the University of Foggia's Department of Agricultural Sciences.

Known among his contemporaries for his studies in the field of agronomy and for his commitment in the political and social fields, in addition to his long career as a teacher in high schools, which saw him working as the author of school manuals that were widely adopted in the classrooms of a large number of Italian institutes, Antonio Lo Re also had a deep interest in technologies related to agricultural sciences, with particular attention to the machinery that the increasingly flourishing European-and, to a more modest extent, also Italian-industry in the second half of the $19^{\text {th }}$ century devoted to agricultural production, in the most authentic spirit of Positivism. It is to this sector of his research that this contribution looks, which aims to shed light on a front of Lo Re's works still rather in the shade, so as to fully reconstruct the multifaceted personality of man and scholar.

\section{Antonio Lo Re: A Brief Biography}

Antonio Lo Re (Figure 1) was born on 18 April 1857, in San Vito dei Normanni, a center located at that time in the province of Terra d'Otranto, in southern Italy. It was his father Vito who reported that his wife Ippolita Nardelli had given birth to a male infant at 2 p.m. in the family home on Strada Tempio Antico, registering him as Vitantonio, as shown by birth certificate no. 84 in the village's records (Nigro, 2007: p. 345).

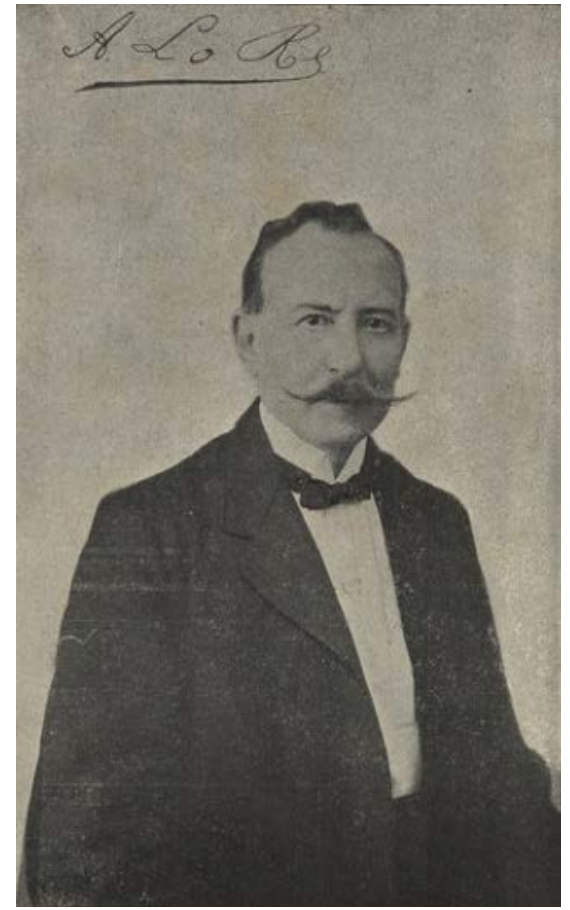

Figure 1. Antonio Lo Re (San Vito dei Normanni, 1857-Foggia, 1920). 
The need to continue his higher education led the young man to move to larger cities, as was often the case at that time. More specifically, Lo Re had the opportunity to attend the Royal High School in Lecce until the age of eighteen. He then moved to Portici, near Naples, where he enrolled in the Royal School of Agriculture, thanks to the economic support provided by a scholarship from the Province of Lecce (Villani, 1904: p. 859). At the time, the school's program offered the most prestigious technical and scientific training in the field of agriculture

It was also the Portici school that, in 1879 , recommended the young man to the Ministry of Education for a teaching position at the Royal Technical Institute in Messina. There, in just four years, Lo Re came to be titolare di prima classe, the highest career grade for secondary school teachers. Already during his Sicilian years-after Messina, he was a lecturer in the city of Girgenti in the province of Agrigento-Lo Re developed a keen interest in publishing and worked as a publicist and a "scientific writer" of articles and dossiers for local newspapers (Villani, 1904: p. 859).

In 1886, at the age of twenty-nine, Lo Re accepted an offer to move to the city of Foggia, in Apulia, as a teacher of Agriculture and Rural Valuation at the Pietro Giannone Royal Technical Institute, which had been formally established the year before, at the recommendation of a member of the Captainate's provincial council. The foundation of this new school was at the center of a heated council debate that had begun in 1882, echoed in the words of a commentator of the time: "There is a great need for agronomic education" for a territory such as the Captainate's, which "encompasses an area of 350 thousand hectares of cultivated land in addition to that suitable for cultivation" and the usefulness of this course in land surveying is based specifically on the assumption that "the scientific measurement of the Italian territory, namely, that which each plot of land related to the geodesic surveys will give [young people] substantial work in the next twenty years" (Lacci, 1886: pp. 15-22). In the thirty-two years he spent at the Royal Institute, Lo Re was both a teacher and headmaster for a total of four mandates.

In addition, he personally oversaw the ten hectares of land donated to the institute in 1886 and intended for botanical gardens, where the scholar carried out numerous cereal trials that he highlighted in specific publications (Lo Re, 1892b; Lo Re, 1894).

Lo Re chose to settle in Foggia. Despite having also received offers for important posts in other Italian regions over the years. It was here that he elected to pursue his career, combining his profession as teacher with his prolific activity as a writer, working on several areas of study that ranged from school manuals to agronomic studies connected to the numerous public positions that he held as an expert in agricultural sciences, up to touching upon economic and social content. Among his many writings, Capitanata triste. Appunti di economia rurale (Sad Captainate. Notes on rural economics, 1895a), Sunto storico dell agri- 
coltura italiana (Historical summary of Italian agricultural, 1902), and Le proletarie del Tavoliere (The proletarian women of Tavoliere, 1910) deserve particular mention.

Lo Re also settled down and raised a family in Foggia. He married Teresa Festa, who gave birth to the couple's only child Guido, on 24 November 1889. The birth took place in the family home on Vico Mastrolillo, 14, behind the building that then housed the Giannone Institute, next to the city's cathedral. Lo Re lived in that very house for the rest of his life, even after his wife's death. It was again in that same "modest little house" that the scholar died at the age of sixty-two on 12 February 1920, struck by the "terrible onslaught of the disease that quickly killed him", as his friend Biagi (1930: p. 109) recalled, and who was next to him in the final moments of his life. It can likewise be seen from the scholar's death certificate, listed at No. 138 in the Municipality of Foggia's 1920 register of deaths, where the deceased's name is accompanied by the sobriquets "knight commander" and "professor".

Biagi praised Antonio Lo Re's firm resolve to disseminate knowledge and expertise, "his abundant scientific output, his well-regarded school textbooks, his numerous lectures, his frequent extraordinary lecture courses" (p. 112). In addition, another of his contemporaries and colleagues, the philologist Domenico Santoro, emphasized in a speech commemorating Lo Re two years after his death that "it is not the frosty scholar, the erudite technician that shines through, but rather the soul of an artist who, with a lean, agile style, full of vibrancy and color, transformed his arid subject into a true work of art" (Santoro, 1922: p. 8).

\section{Machines, Tools, Agriculture, and Animal Husbandry}

"I dictated these lessons for the first time during this year that is about to end, to my students in the land-surveying section of the Royal Technical Institute, duly expanding the teaching of agriculture" (Lo Re, 1892a: p. III). With these words, Antonio Lo Re introduced the book he had written, Lezioni elementari di zootecnia e tecnologia agraria secondo i recenti Programmi governativi per gli istituti tecnici (Elementary lessons in animal husbandry and agricultural technology according to the recent government Programs for technical institutes, Figure 2). A best-seller among late $19^{\text {th }}$-century Italian school manuals (Bianchini, 2000; Chiosso, 2013), he concentrated on writing to address the haste and incompleteness he had personally encountered in the national panorama of agrotechnical texts. The author himself summed up the objective as follows: "that the most important technological knowledge is summarized and the number is increased of those who can in any way apply or disseminate it" (Lo Re, 1892a: p. IV).

The organization of the contents of the Lezioni elementari complied with the requirements of the ministerial guidelines in force at the time, as set out in Royal Decree no. 622 of 2 October 1891. The four sections of the book were dedicated respectively to animal husbandry (12 lessons), dairy farming (4 lessons), the art 


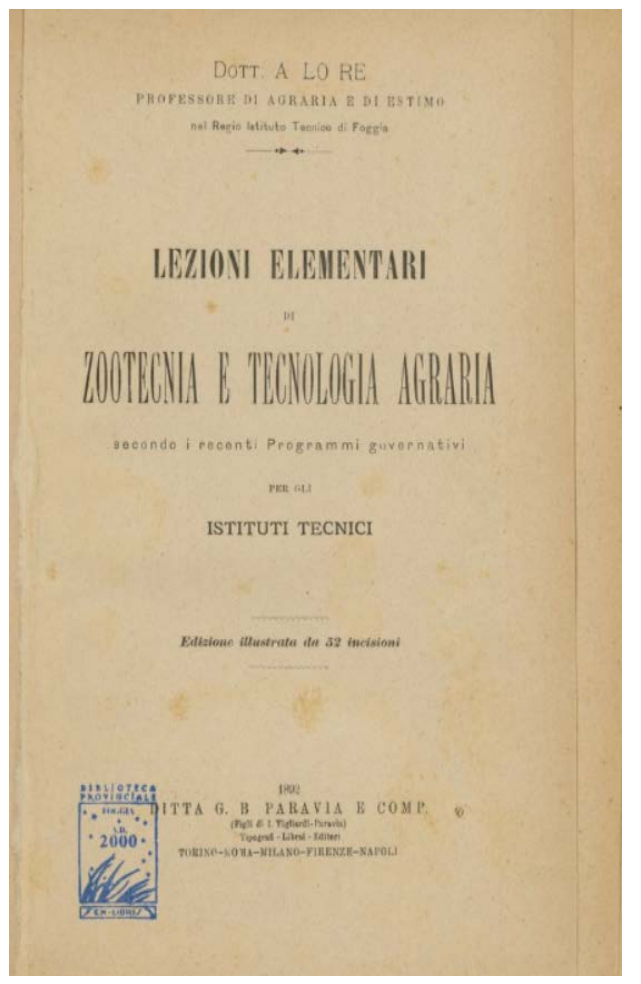

Figure 2. Front page of the book Lezioni elementari di zootecnia e tecnologia agraria (Lo Re, 1892a).

of wine (7 lessons), and oil mills (5 lessons), for a total of 28 lessons. He frequently cited scientists, mathematical formulas, illustration, classifications of animal and plant breeds and species in the different categories addressed, information on diseases and adulteration processes that could be present, without overlooking references to specific legislation on the subject.

The manual's pages also offer an interesting insight into the inventory of machinery, tools, rooms, and processing techniques used on farms at the end of the $19^{\text {th }}$ century in southern Italy, in one of the areas traditionally most suited to the extensive cultivation of large tracts of land (Bevilacqua, 2005: p. 39) and the breeding and processing of derivative products. The book mentions about thirty machines or tools, often accompanied by the author indicating a specific model that he considered more effective and efficient than the others.

In the animal husbandry part, ample space is reserved for sericulture, a particularly widespread crop in the $19^{\text {th }}$ century. Even someone as famous as Louis Pasteur (1870) devoted his attention to it, carrying out studies to fight an epidemic pathogen that risked seriously compromising the thriving business. Lo Re (1892a: p. 61) suggested the use of an artificial incubator for Orlandi model silkworms. Later, in order to neutralize the chrysalises to produce marketable silkworms, rather than resorting to the "heated air from ovens in special although expensive appliances", the author recommended a "very simple, easy-touse, and very inexpensive device", a cylindrical tin receptacle connected to a matrass with some carbon disulfide (pp. 68-69). 
In the chapter on dairy farming - a sector where the push towards needed controls and regulations was ever stronger (Marigliano, 2019), Lo Re highlights the lactodensimeter developed by Quevenne to measure the density of milk (p. 73). He then mentions the Lefeldt creamometer that determines "the amount of cream in the milk" (p. 73); an instrument designed by Walter "used to check the wholesomeness of milk" (p. 74); the Swartz refrigerating unit (p. 75); a stove for cooking curd (pp. 77-78), a mechanical centrifugal skimmer (pp. 79-80); the Lefeldt churn that "is like a small barrel, inside of which are three partitions, one perforated and the other two meshed, so that as the churn turns, the cream sticks to it, forming butter" (p. 82); and finally the skimmer and cutter, tools for working the curd (pp. 85-86).

The section dedicated to winemaking contains abundant technological references, in line with the period of great change and experimentation that characterized the wine sector in the second half of the $19^{\text {th }}$ century, owing also to the nascent chemical industry's contributions (Antonaros, 2006: pp. 182-206). First, Lo Re mentions the hydrometers, "tools that can determine the density of the must" (p. 90). Of particular note among these are the Von Babo mustimeter and the Guyot gleucometer (p. 91); the burette developed by Mohr to filter the must (pp. 91-92); the Torinese Mure's pressing shed (pp. 95-96), the "Mabille system" presses, with "multiple levers and continuous pressure" (p. 97); another machine by Von Babo for the aerating the must ("it has been proved, that by passing a current of air using a bellows in the must, the fermentation is more complete and the wine less alterable; the glucose decreases and the alcohol increases; nitrogen, i.e., the albuminoids, decreases, resulting in the wine having greater preservability", p. 101); a hydraulic bung to be placed in the barrel during the fermentation process (pp. 108-109); a Henrich model valve transfer pump (pp. 110111); a Moll vaporizer for maintaining the barrels (p. 112); a Salleron still, namely, a small distiller to measure out the alcohol (p. 115); and finally a Dutch-produced filter for clarifying the wine (p. 118).

The overview of machinery dedicated to the olive-oil sector, also expanding rapidly at the end of the $19^{\text {th }}$ century (Montaudo, 2019), is more concise, with the discussion in the last section of the book. Having provided a series of suggestions for the internal layout of an oil mill, Lo Re focuses on describing a millstone for crushing olives (p. 130), different models of screw, hydraulic, or perforated presses (pp. 132-134), and a mechanical filter (pp. 135-136).

All the machines mentioned are illustrated, often with a legend that uses capital letters that the author then uses in the body of the text to more easily describe the technical characteristics and the various components of the individual piece of machinery. For example, Lo Re explains to his young readers how many and which parts the water presses are divided into (Figure 3). "These, in general, include a sturdy, thick-walled cast-iron cylinder, in which water is sent using a pressure pump. Inside, a piston moves this cylinder, which has a reservoir at the top where the column of cages is supported. [...] A is the cylinder; B the piston; 


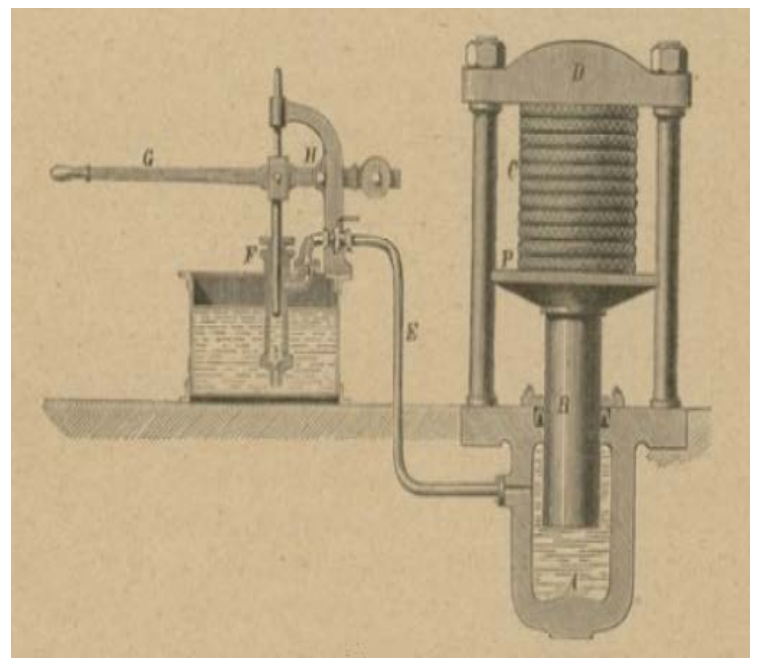

Figure 3. Illustration of a water press for crushing olives (Lo Re, 1892a: p. 133).

C the columns; [and] D the resistance. $\mathrm{B}$ ends with plate $\mathrm{P}$ on which the press cages are placed. E is a copper tube that connects the pump body with the cylinder's internal chamber. $\mathrm{F}$ is the box in which the pump or pump system is located and which fills with water. $G$ is the lever that the workers operate and whose fulcrum is in $\mathrm{H}$. Pipe $\mathrm{E}$ has both a safety and a drain valve. By operating this [latter] valve, the water contained in the press cylinder is discharged directly and the pressure ends" (pp. 133-134).

Antonio Lo Re's work on the conception and writing of school manuals did not end with the Lezioni elementari and important were also the works produced for another type of school where the author taught, the "normal schools". the book Nozioni di agraria per le tre classi delle scuole normali maschili e femminili, secondo il programma governativo (Notions of agriculture for the three classes of male and female normal schools, according to government program, 1898a) should be recalled that-as Carlo Villani pointed out in 1904 (p. 860)"had three editions of three thousand copies each within just two years, and which was favorably received in all the kingdom's normal schools". as the author makes clear in the very short preface, the objective of this publishing initiative was to focus "more on topics directly linked to day-to-day needs as well as to the future and prosperity of our nation's industries, rather than on what science has in common with agriculture" (Lo Re, 1898a: p. 3). Lo Re must have used another work from the year before, L'agraria nella economia domestica: lezioni raccolte dalle alunne della Regia scuola normale superiore femminile in Foggia. I corso (Agriculture in the home economics. lessons collected by the students of Royal female normal school in Foggia. $1^{\text {st }}$ course, 1897), to familiarize himself with the design of the subject content referring to a course of study distinct from the technical one in which he had always worked.

Lo Re taught agriculture in the male and female sections of Foggia's normal high school, named after Francesco Ricciardi and Carolina Sossio Poerio respec- 
tively. This is confirmed by the Calendario generale del Regno d Italia pel 1900 compilato a cura del Ministero dell'Interno (General calendar of the Kingdom of Italy for 1900, written by Ministry of Internal affairs), which lists the scholar as a professor of agriculture (Ministero dell'Interno d'Italia, 1900: p. 486). Separated into all boys or all girls, the normal schools were aimed at training future elementary-school teachers and were structured as three-year courses (Genovesi, 2004: p. 111). With the purpose of reforming the normal schools and of raising their academic standards, the Gianturco Law of 12 July 1896 introduced the teaching of rural technology. Thus explaining Lo Re's work in this direction: with this discipline, "our women will be able to bring to school and family new profitable jobs, helpful advice, [and] effective aid in order to help raise the household's net income; skillfully, hygienically, and inexpensively producing what they can produce; and learning to choose and evaluate what is needed to nourish their families [...] [by] producing, or rather transforming things so they become useful rather than useless and, in this way, acquire value" (Lo Re, 1897: pp. 6-7). The book's table of contents clarifies what Lo Re had in mind when he talked about production: bread, meat, milk, butter, cheese, wine, and olive oil. In 16 lessons, the kitchen pantry is shown through its variety of foods and molds the general concept of home economics, to which Lo Re refers repeatedly in the text.

In 1911, Lo Re wrote the last of his school manuals, the Nozioni di agraria per gli Istituti Tecnici e le Scuole normali maschili e femminili (Notions of agriculture for Technical Institutes and male and female normal Schools, Paravia, Turin), articulated into three sections (agronomy; cultivated plants and technology; Livestock, technology, and accounting). Reissued in 1920, he brought together the two examples to which he had dedicated his writing and research efforts over the previous twenty years.

\section{The Threshing Machine}

Lo Re also left an important contribution to the history of machinery in Italy's south, unearthing a threshing machine described in an unpublished letter by the doctor and agronomist Giuseppe Rosati (1752-1814). In a short essay published in 1908, Lo Re used Rosati's handwritten letter to describe all the structural details of the threshing machine conceived and made in Apulia in the late $18^{\text {th }}$ century. It would have been irretrievably lost had it not been for Lo Re's receptivity and the "diligent librarian Giovanni Bucci-Fania" who, having found Rosati's signed letter, gave it to the scholar (Lo Re, 1908: p. 3).

Dated 25 September 1793, Rosati's letter was addressed to Foggia's Governor of Royal Customs and was meant to acquaint authorities with the work of his friend from Foggia Michele Schinco, a machine builder and maker of the threshing machine itself. Although neither the machine's design nor its operating diagram appeared in the letter, Lo Re had Pagliochini, a colleague and drawing teacher, complete a meticulous graphic reconstruction of the threshing machine on the basis of the description contained in the letter. 
Lo Re's evidence lets the threshing machine be placed not only in the local context of its invention, but also within the debate that continued to see these machines play a key role in northern Apulian agriculture for more than a century. In 1786, Andrew Meikle built his threshing machine, developing a machine capable of exploiting an operating principle based on the combined action of a rotating cylinder and a concave, thus ending the experiments that had been in progress since the century before (Beaumont \& Higgs, 1954: p. 9).

The threshing machine had a hexahedral shape. Closed on four sides, but open both above and below, it reached an overall height of just under $2 \frac{1}{2}$ meters. The details of the machine's construction shed light on its main functions. In Figure 4, a view from above shows both the opening for inserting the sheaves of wheat and a roller (the beater drum) equipped with a series of fixed scutchers. Figure 5 displays, from a different angle, a longitudinal cross-section of the machinery, with a crank-operated beater drum and a second beater drum in a fixed position. Figure 6 illustrates the beater drum's drive mechanism, the main wheel (with its crank), and the drive mechanism of the separators. Lastly, the crosssection (Figure 7) highlights the structure of the beater drum (top) and of the separator (bottom), letting only the smallest objects pass through.

The sheaves of wheat were introduced from above, passing through the iron scutchers attached to the moving beater drum and to the second stationary beater drum. They then fell into the two wheels that made up the separators. These latter let through only small pieces and strands of straw (collected in a container placed under the machine), while retaining everything else. According to Rosati's letter, the threshing machine was quite efficient as it was generally able to thresh one sheaf of wheat per minute, employing a total of just five workers (two to operate the crank, one to hand up the sheaves of wheat, another to put them in the machine and the last to remove the debris from the separators).

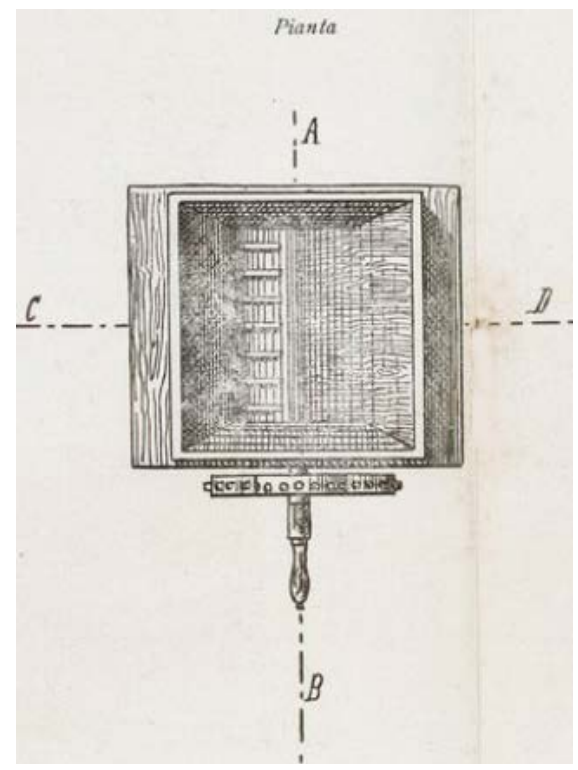

Figure 4. Top opening of the threshing machine (Lo Re, 1908: p. 11). 


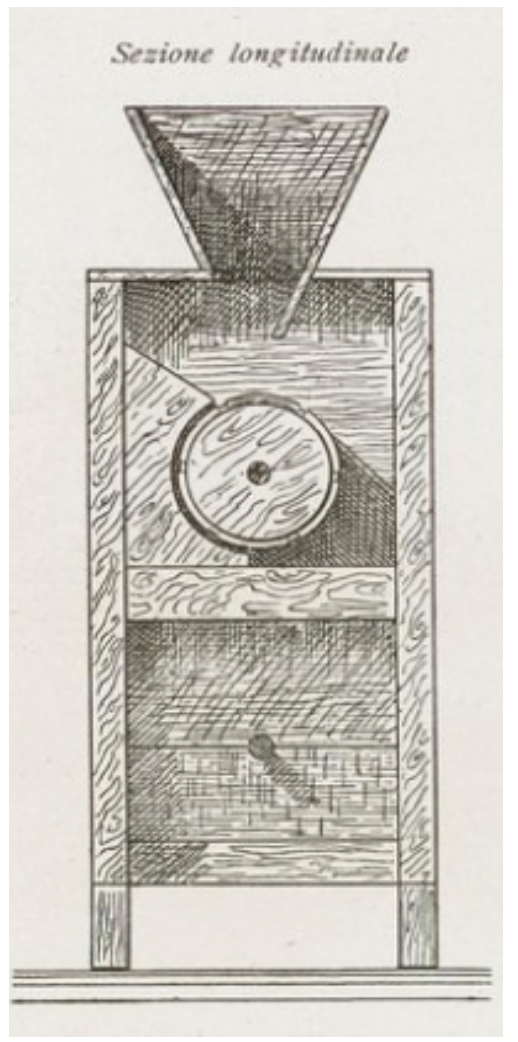

Figure 5. Roller and fixed beater drum (Lo Re, 1908: p. 11).

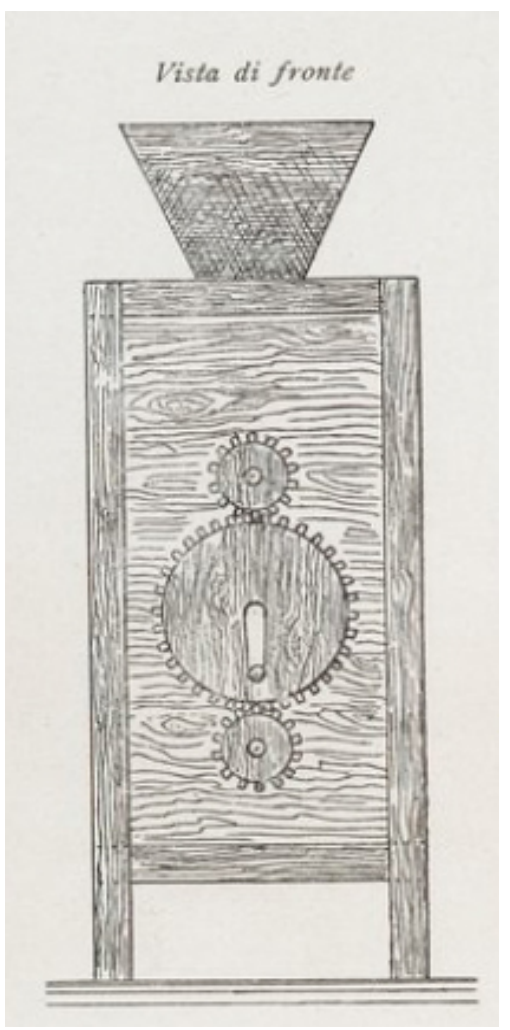

Figure 6. Beater drum and separator drive mechanisms (Lo Re, 1908: p. 11). 


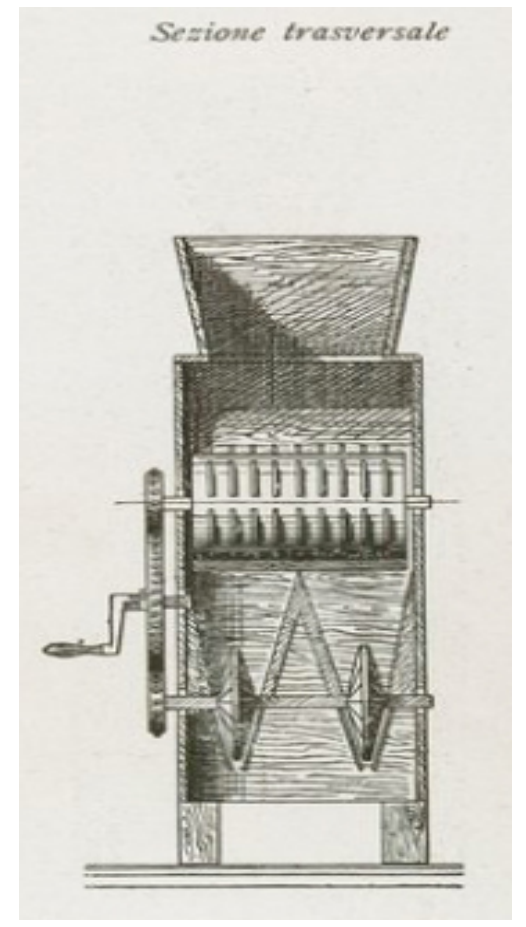

Figure 7. Structure of the beater drum and separator (Lo Re, 1908: p. 11).

Nevertheless, as evidenced by a report sent in 1811 to the Captainate Royal Economic Society, which immediately followed the Murat Decree of 16 December 1810 introducing the use of threshing machines in agriculture, Rosati was never particularly supportive of using mechanical threshing equipment, deeming it inefficient in comparison to the work performed using the more traditional techniques of human or animal trampling. On that occasion, starting from the assumption that "every mechanical problem is carried out by combining three inseparable items, which are: power, time, and effect' (Rosati, 1838: p. 111). Rosati made it clear how these elements were related to each other. To improve processing speed (time), it is necessary to increase the power or lower the expectations for the result (effect). To use less power, it is necessary to lengthen the processing time or decrease the result. Finally, to increase results (effect), the power needs to be increased or the processing time lengthened.

According to Rosati, a machine that generally runs by multiplying human or animal strength is limited by the fact that the more it succeeds in increasing muscle strength, the slower it becomes in performing the task, and thus, requires more time to do the work. With regard to the specific case of threshing in Apulia, it was carried out nonstop for a maximum of 10 hours a day during the hottest time of day so as to maximize the quality of the product. Consequently, the threshing machine was generally not very useful.

By no means was Rosati's unambiguous position isolated, as it represented a fairly widespread tendency in Europe where the question "How does your Thrashing Machine succeeded-is it complicated and expensive?” (MacDonald, 1975: 
p. 66) had become commonplace.

On the other hand, while acknowledging the progress made in agriculture by steam threshing machines (Lo Re, 1913: p. 179), Lo Re himself did not fail to point out that their spread was hampered by the geographical and logistical difficulties arising from the disposition of the northern Apulian landscape. At a time of the greatest expansion of technological applications to agriculture, Lo Re, with a careful look at his own territory, did not hesitate to speak of a return to natural energy, writing that "the forces of wind and water can be turned into considerable wealth” (Lo Re, 1895b: p. 63).

\section{Conclusion}

The frequent references to tools and machines that can be traced in the works of Antonio Lo Re under consideration, are rarely reflected in the reference bibliography on the researches of the agronomist, bibliography who has neglected the recurrent interest of the Apulian scholar for the theme of industrial technology in use in agricultural and livestock farms of the time. Proof of this is the care and precision of the drafting of the description texts of the machinery, which go into the details of the materials and components, of the operation and even of the efficiency of the performances, compared to the purchase and management costs. Even the extensive review of sketches and drawings goes in the same direction of a clear documentary will, as if Lo Re were guided by the intention of "photographing" the state of the art of the agricultural industry, in its various branches (oenological, dairy, oil, to give just a few examples).

Lo Re also looks with interest at the past, at the history of industrial technology in the agricultural field and its rapid development over the span of just over a century, in the years between the end of the eighteenth century and the beginning of the twentieth century, which saw the industrial revolution also take root in lands, such as those of Southern Italy, which have always been suited to large estates, rather than to a more modern concept of agricultural business. Lo Re's study of the threshing machine borrowed from Giuseppe Rosati succeeds in giving new life to a machine that would otherwise have been forgotten, making it an element of conjunction between suggestions of the past, instances of the present and future perspectives of the technological evolution of agricultural industry in the Italian and European context.

From the point of view of the history of engineering, Lo Re's works don't seem to be particularly influent at an international level, as regards the evolution of machines, but there is no doubt that they are avant-garde if they're contextualized in the emergency of technical education that characterized the Southern Italy of the time.

\section{Conflicts of Interest}

The authors declare no conflicts of interest regarding the publication of this paper. 


\section{References}

Antonaros, A. (2006). La grande storia del vino. Tra mito e realtà, l'evoluzione della bevanda più antica del mondo. Bologna: Pendragon.

Beaumont, O., \& Higgs, J. W. Y. (1954). Agriculture: Farm Implements. In C. Singer, E. J. Holmyard, A. R. Hall, \& T. I. Williams (Eds.), A History of Technology (Vol. IV, pp. 1-12). Oxford: Clarendon Press.

Bevilacqua, B. (2005). Breve storia dell'Italia Meridionale dall'Ottocento a oggi. Roma: Donzelli Editore.

Biagi, B. (1930). Profili di scienziati. Foggia: Frattarolo.

Bianchini, P. (2000). Una fonte per la storia dell'istruzione e dell'editoria in Italia: Il libro scolastico. Contemporanea. Rivista di storia dell' 800 e del '900, 1, 175-182.

Chiosso, G. (2013). L'Italia alfabeta: Libri di testo e editoria scolastica tra Otto e primo Novecento. In A. M. Mandich, \& B. Ranzani (Eds), L'editoria italiana per le lingue. Atti della giornata di Bologna, 12 gennaio 2006 (pp. 125-146). Bologna: CLUEB.

Genovesi, G. (2004). Storia della scuola in Italia dal Settecento ad oggi. Bari-Roma: Laterza.

Lacci, V. (1886). Su lo impianto dello Istituto tecnico Pietro Giannone in Foggia. Considerazioni. Foggia: Stabilimento Tipografico Pollice.

Lo Re, A. (1892a). Lezioni elementari di zootecnia e tecnologia agraria secondo i recenti Programmi governativi per gli istituti tecnici. Torino: G. B. Paravia.

Lo Re, A. (1892b). Riordinamento dell'Orto botanico e impianto d'un orto agrario sperimentale. Relazione e progetto del dott. prof. A. Lo Re. Foggia: Tip. Lit. D. Pascarelli.

Lo Re, A. (1894). Il campo sperimentale di Mortellito per lo studio dei concimi e della azione del sovescio sulla produzione del frumento. Roma: Bertero.

Lo Re, A. (1895a). Capitanata triste. Appunti di economia rurale. Cerignola: Ruocco \& Bufano.

Lo Re, A. (1895b). Economia della industria agraria. Foggia: Modugno Editore Libraio.

Lo Re, A. (1897). L'agraria nella economia domestica: Lezioni raccolte dalle alunne della R. scuola normale superiore femminile in Foggia. I corso. Foggia: Tip. P. Leone.

Lo Re, A. (1898a). Nozioni di agraria per le tre classi delle scuole normali maschili e femminili, secondo il programma governativo. Torino: G. B. Paravia.

Lo Re, A. (1898b). Sul recente miglioramento della Villa Comunale di Foggia. Relazione al sindaco. Foggia: Ferreri-Trifiletti.

Lo Re, A. (1902). Sunto storico della agricoltura italiana. Foggia: Tip. U. Zobel.

Lo Re, A. (1908). Una trebbiatrice pugliese del Settecento. Piacenza: Porta.

Lo Re, A. (1910). Le proletarie del Tavoliere. Pescara: E. Trifiletti.

Lo Re, A. (1911). Nozioni di agraria per gli Istituti Tecnici e le Scuole normali maschili e femminili. Torino: G. B. Paravia.

Lo Re, A. (1913). Capitanata. Nuovi studi economici. Cerignola: Pescatore.

MacDonald, S. (1975). The Progress of the Early Threshing Machine. Agricultural History Review, 23, 63-77.

Marigliano, M. (2019). Gli standard qualitativi del latte tra scienza, industria e allevamento. Italia, prima metà del sec. XX. In E. Ritrovato, \& G. Gregorini (Eds.), Il settore agroalimentare nella storia dell'economia europea (pp. 330-343). Milano: FrancoAngeli.

Ministero dell'Interno d'Italia (1900). Calendario generale del Regno d'Italia pel 1900 compilato a cura del Ministero dell'Interno (1900). Roma: Tipografia Ditta L. Cecchini 
Editrice.

Montaudo, A. (2019). Il settore oleario nel Mezzogiorno in età moderna. In E. Ritrovato, \& G. Gregorini (Eds.), Il settore agroalimentare nella storia dell'economia europea (pp. 298-313). Milano: FrancoAngeli.

Nigro, M. (2007). Antonio Lo Re, il salentino immigrato nella triste Capitanata. In F. P. De Ceglia (Ed.), Scienziati di Puglia (pp. 345-347). Bari: Adda Editore.

Pasteur, L. (1870). Études sur la maladie de vers a soie, moyen pratique assuré de la combattre et d'en prévenir le retour. Parigi: Gauthier-Villaurs.

Rosati, G. (1838). Su la trebbiatura, e su la inutilità delle macchine finora inventate. Giornale degli Atti della Reale Società Economica di Capitanata, 4, 109-120.

Santoro, D. (1922). Discorso in commemorazione di Emilio Perrone e Antonio Lo Re. Foggia: Tip. U. Zobel.

Villani, C. (1904). Scrittori ed artisti pugliesi antichi, moderni e contemporanei. Trani: V. Vecchi Tipografo Editore. 